\title{
Teachers' Technological Pedagogical Content Knowledge Self-Efficacies
}

\author{
Ibrahim Yasar Kazu ${ }^{1}$, Pınar Erten ${ }^{2}$

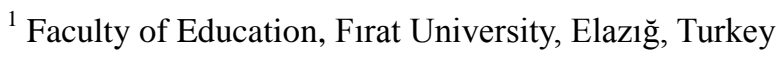 \\ ${ }^{2}$ Firat University, Institute of Education Sciences, Elazı ̆ \\ Correspondence: Ibrahim Yasar Kazu, Faculty of Education, Firat University, Elazığ, Turkey.
}

Received: October 30, 2013 Accepted: November 11, 2013 Online Published: January 26, 2014

doi:10.11114/jets.v2i2.261

URL: http://dx.doi.org/10.11114/jets.v2i2.261

\begin{abstract}
The aim of this study was to determine teachers' views on technological pedagogical content knowledge (TPACK), their self-efficacy, and whether these views changed according to sex, age, period of service, faculty graduated from, branch, access to the internet, the use of technology level, and access to in-service training which is oriented to the use of technology. Teachers' self-efficacies which are oriented to TPACK and its sub-dimensions known as technological knowledge (TK), content knowledge (CK), pedagogical knowledge (PK), pedagogical content knowledge (PCK), technological content knowledge (TCK) and technological pedagogical knowledge (TPK) were determined to be at a high level. According to this study, teachers' self-efficacy perceptions on TK, CK, PCK, TCK and TPACK did not change according to sex while the self-efficacy perceptions on PK and TPK changed according to sex. It was concluded that the self-efficacy perceptions of female teachers in these dimensions were higher when compared to those of male teachers. According to the present study, teachers' self-efficacy at TK and PCK changed according to age and the period of service, while self-efficacy at CK, PK, TCK, TPK and TPACK did not change according to these variables. In addition, a significant difference was determined between teachers' self-efficacy perceptions on TK and TPK according to the faculty graduated from. It was detected that the self-efficacy levels of classroom teachers on CK, TPACK, PCK and TCK were higher when compared with those of branch teachers. It was also concluded from this study that teachers' self-efficacy perception of TPACK did not change according to the situation of access to internet in the school in which they held office and that their efficacy was adequate. Teachers who thought that their self-efficacy in the use of internet was sufficient had higher levels of self-efficacies in TK, TCK, TKP and TPACK compared with other teachers. According to the present study, the in-service training that teachers receive on how to use the internet has more positive effects on CK and PCK compared with their self-efficacy in other dimensions.
\end{abstract}

Keywords: technology, content, pedagogy, technological pedagogical content knowledge, teacher self-efficacy

\section{Introduction}

Today, all individuals within the educational system have been affected by the use of the internet. The need for individuals to be involved in technological change and development, and their being educated for this, has arisen. Now learning environments are being enhanced with technology and changes in course content, classroom management and applications according to these technologically enhanced arrangements, and this has required that teachers should have the necessary knowledge and skills for the integration of technology in education. The need has arisen for teachers to have a structure which provides for that integration of technology in their departments and branches.

Along with the digital technologies, technical competence and technical literacy have appeared. Technical competence and technical literacy require having knowledge and skills on knowing how to use the technologies which will provide comprehensive learning and teaching and also on the power and limitations of these technologies. Classroom technologies have been developed beyond the use of technologies which simply offer education and they have offered the potential for a transformation of pedagogy and its content. Teachers' roles changed into choosing pedagogical approaches and choosing the appropriate technology for the content to discuss and also being the designer of the curriculum (Kereluik, Mishra \& Koehler, 2010: 13).

Teachers are people who receive education in higher education institutes on general knowledge, the special field, and pedagogical formation, and are involved in education services in formal and informal educational institutions (MEB-Öğretmen Yetiştirme ve Geliştirme Genel Müdürlüğü, 2012). So, pedagogical content knowledge in which 
content knowledge and pedagogical knowledge about teachers' content knowledge, pedagogical knowledge, teaching processes and realizing teaching which determine how much they know about their branches are emphasized became a subject to be examined (Shulman, 1986). It has been emphasized that content and pedagogy are inseparable parts of understanding (Shulman, 1986: 6); the basic skills, content knowledge and general pedagogical skills which are required by education should be integrated and their efficacy is of considerable importance (Shulman, 1987). So, the concept of Technological Pedagogical Content Knowledge (TPACK) which offers the opportunity for teachers to effectively integrate technology to training applications was developed (Koehler \& Mishra, 2005; Mishra \& Koehler, 2006; Koehler, Mishra \& Yahya, 2007; Koehler \& Mishra, 2008; Mishra \& Koehler, 2008; Harris, Mishra \& Koehler, 2009; Koehler \& Mishra, 2009; Schmidt et al., 2009).

TPACK emerged via the interaction of pedagogy and technological knowledge. TPACK requires that teachers use their pedagogical strategies in their classrooms and that they be equipped with knowledge on various technologies (Shin et al., 2009). TPACK has crucial effects on teachers' training and improvement (Koehler et al., 2007). Technological Pedagogical Content Knowledge fights the teachers' corner by regarding teachers as curriculum planners who transform existing technical tools for pedagogical purposes (Kereluik et al., 2010). TPACK is a theoretical framework which provides teachers with the means to plan effective training programs with information and communication technologies and to integrate these programs (Rocha, Mota \& Coutinho, 2011). This concept is comprised of technological content knowledge, technological pedagogical knowledge, pedagogical content knowledge and technological pedagogical content knowledge that are composed by the integration of concepts such as technological, pedagogical and content knowledge. The domains of content, pedagogical and technological knowledge are in interaction with each other (Mishra \& Koehler, 2006; Savaş, 2011; Şahin, 2011; TPACK.org, 2013):

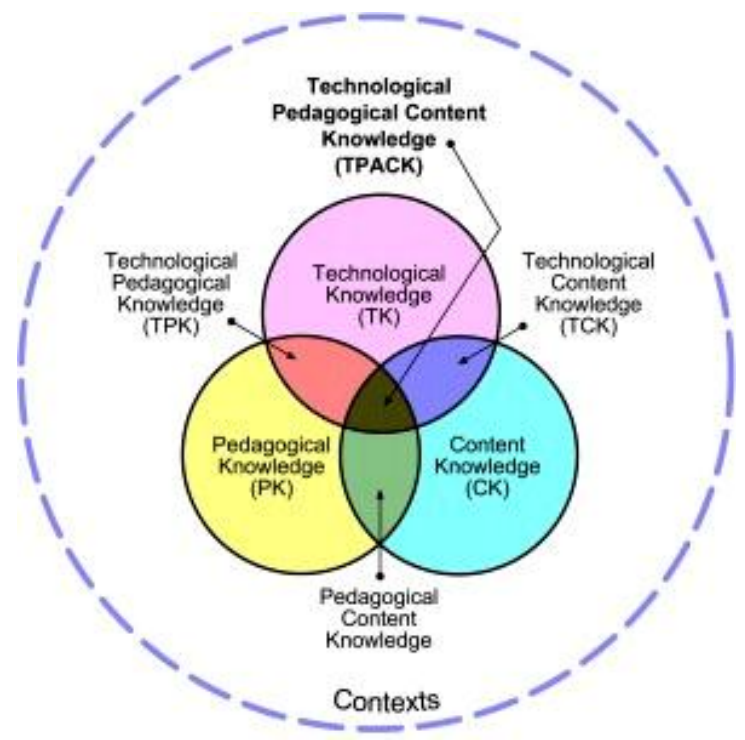

Figure 1. Framework of Technological Pedagogical Content Knowledge (TPACK) and its components (Koehler \& Mishra, 2008; TPACK.org, 2013).

Content Knowledge (CK) is the amount of the actual knowledge and organization in the mind of the teacher (Shulman, 1986: 9). Content knowledge is the knowledge of the subject matter that is to be learned or taught. It involves the nature of the understanding of information and questioning on different domains for the teachers (Koehler \& Mishra, 2005; Mishra \& Koehler, 2006; Koehler et al., 2007; Koehler \& Mishra, 2008; Mishra \& Koehler, 2008; Harris et al., 2009; Koehler \& Mishra, 2009; Schmidt et al., 2009).

Pedagogical Knowledge (PK) is knowledge that includes the strategies and principles of classroom management and organization in education (Shulman, 1987: 8). It is the knowledge of learning-teaching processes, applications or methods. It is the knowledge that is oriented to general classroom management skills, lesson planning, student assessment and knowing the learning styles of students and the practice of teaching accordingly (Koehler \& Mishra, 2005; Mishra \& Koehler, 2006; Koehler et al., 2007; Koehler \& Mishra, 2008; Mishra \& Koehler, 2008; Harris et al., 2009; Koehler \& Mishra, 2009; Schmidt et al., 2009). Teachers embrace additional methods to bring out the aimed for student behaviors and to support students. Involving the appropriate technology in the classroom depends on the pedagogical purposes of the teacher. Pedagogy should lead the technology; the reverse situation should not be valid 
(Hammond \& Manfra, 2009: 163).

Technological Knowledge (TK) is oriented to various technologies and their use (Koehler \& Mishra, 2005; Mishra \& Koehler, 2006; Koehler et al. 2007; Koehler \& Mishra, 2008; Mishra \& Koehler, 2008; Harris et al., 2009; Koehler \& Mishra, 2009; Schmidt et al., 2009). Technology is used to support the teacher while giving the content to the student, to support the dialog between the teacher and the student, or for presenting the content to the students for the students to conduct their research on the content (Hammond \& Manfra, 2009).

Pedagogical Content Knowledge (PCK) includes the understanding that provides the learning of both tough and easy subjects (Shulman, 1986: 9). It is the knowledge of different teaching methods for different subjects (Koehler \& Mishra, 2005; Mishra \& Koehler, 2006; Koehler et al., 2007; Koehler \& Mishra, 2008; Mishra \& Koehler, 2008; Harris et al., 2009; Koehler \& Mishra, 2009; Schmidt et al., 2009). It is the blending of pedagogy and content within the understanding of the presenting of certain subjects and dealing with the problems in education, the way of organizing, representing and adapting different student interests and skills (Shulman, 1987: 8).

Technological Content Knowledge (TCK) is the knowledge of the presentation of technology and subject matter. This knowledge provides for the flexibility of use of the appropriate technologies for educational purposes (Koehler \& Mishra, 2005; Mishra \& Koehler, 2006; Koehler et al., 2007).

Technological Pedagogical Knowledge (TPK) is the knowledge of how to use technology to adopt different teaching methods (Koehler \& Mishra, 2008; Mishra \&Koehler, 2008; Harris et al., 2009).

Technological Pedagogical Content Knowledge (TPACK) is the knowledge of the use of technology in various subjects and practicing teaching methods. This knowledge makes the learning of the subject for the student easier with appropriate pedagogy and technology (Koehler \& Mishra, 2009; Schmidt et al., 2009). It is aimed to go beyond techno-centrism to help teachers in creative thinking. This will be possible with the practice of TPACK, the process of curriculum sample which will reflect teachers' experiences to be more professional and bringing a new dimension to technology for educational purposes (Mishra, Koehler, Zellner \& Kereluik, 2012: 4).

TPACK is the base for effective teaching with technology which includes an understanding of how to present concepts with technology, how to use pedagogical techniques that use technology in teaching the content indirectly, the knowledge of the concepts which make learning easier or harder, the knowledge of how the technology will be helpful for learning, the knowledge of the students' previous knowledge and the knowledge of epistemological theories, the knowledge of how to use technology in building new information onto existing knowledge and which also includes the development of new epistemologies, or strengthening the old ones (Mishra \& Koehler, 2006: 1029; Koehler et al., 2007: 743; Koehler \& Mishra, 2008: 17-18; Mishra \& Koehler, 2008: 10; Harris et al., 2009: 401; Koehler \& Mishra, 2009: 66). The frame of the TPACK model requires that teachers should develop a detailed, complex, fluent and flexible knowledge of all the components, and teachers should find the appropriate technology and should know how and why to use this technology in the teaching process and that they should practice the technology (Koehler et al., 2011). TPACK and the choices of teachers affect in-class behaviors and student performance (Bos, 2011) and so TPACK is a required information form to enable teachers to integrate technology in education (Kereluik et al., 2010).

Teachers' beliefs and experiences are also effective in the involvement of information and communication technologies in education (Angeli \& Valanides, 2009: 159). Self-efficacy, which refers to an individual' dealing with different challenges, the ability to accomplish an activity, and his/her belief in his/her own capacity (Senemoğlu, 2010) is important in the practice and development of TPACK. The practice of TPACK and teachers' beliefs change and develop according to the application (Shin et al., 2009). Teachers' perception of information technologies and their views on, and practice in the use of these technologies are important in terms of determining the present progress in technology enhanced learning. So, teachers' perceptions of self-efficacy are oriented to their understanding of education that changes and develops depending on the technology (Ekici, Ekici \& Kara, 2012). When self-efficacy increases, the level of performance, the level of dealing with challenges, the belief in accomplishing the tasks and success in learning also increase (Aşkar \& Davenport, 2009). Teachers should improve themselves in order to harmonize the existing technology with pedagogical and professional competence, to easily overcome the possible problems, to find appropriate solutions and develop new plans.

\section{Purpose}

The aim of this study was to determine teachers' opinions on their self-efficacy in technological pedagogical content knowledge. The determined sub-purposes under this main purpose are as follows:

1) What are the opinions of teachers regarding their self-efficacy in technological pedagogical content knowledge? 
2) How do the opinions of teachers on their self-efficacy in technological pedagogical content knowledge change according to sex, age, period of service, the faculty graduated from, branch, the situation of access to technology, and the level of use of the technology, and the situation of in-service training oriented towards the use of technology?

\section{Method}

This study which aimed to determine teachers' opinions on their self-efficacy on technological pedagogical content knowledge was prepared according to a scanning method.

\section{Population and Sample}

The population of the study was composed of primary school teachers who held office in the Elaziğ city center in Turkey in the academic year 2011-2012. A random sampling method was used to choose the sample and the study group was created. The participants were 280 teachers who held office in 15 primary schools situated in the Elazı $\breve{g}$ city center. Information on the participants is given in Table 1.

Table 1. The personal details of teachers within the study group

\begin{tabular}{lcc}
\hline Gender & f & \% \\
\hline Female & 128 & 45.7 \\
Male & 152 & 54.3 \\
\hline Age & 12 & \\
\hline Between the ages of 21-25 & 34 & 4.3 \\
Between the ages of 26-30 & 51 & 12.1 \\
Between the ages of 31-35 & 183 & 18.2 \\
36 years old and over & & 65.4 \\
\hline Duration of Service & 28 & 10.0 \\
\hline 1-5 years & 37 & 13.2 \\
6-10 years & 70 & 25.0 \\
11-15 years & 72 & 25.7 \\
16-20 years & 73 & 26.1 \\
21 years and over & & 49.6 \\
\hline Graduated from the Faculty & 139 & 4.6 \\
\hline Education (FE) & 13 & 23.2 \\
Technical Education (FTE) & 65 & 22.5 \\
Science and Letters (FSE) & 63 & \\
Other & & 51.8 \\
\hline Branch & 145 & 48.2 \\
\hline Classroom Teacher & 135 & \\
Branch Teacher & & 72.5 \\
\hline Access to Technology & 203 & 27.5 \\
\hline Yes & 77 & 18.9 \\
No & 53 & 81.1 \\
\hline The Level of Using Technology & 227 & \\
\hline Insufficient & & \\
Sufficient & 176 & \\
\hline In-service Training & 280 & \\
\hline Received & & \\
Not received & & \\
\hline Total & & \\
\hline & & \\
\hline
\end{tabular}

In this study, the faculties for which teachers choose the option of "other" are as follows: faculties of engineering, religious studies, academies of physical education and sport, faculties of aquaculture, management, fine arts, agriculture, languages, history and geography, vocational training, associate degrees, undergraduate education, open education faculties, and schools of economics and administrative sciences. Also, the participant teachers of this study were from the branches of Turkish (6.8\%), information technologies (3.6\%), mathematics $(5.0 \%)$, painting $(7.0 \%)$, social sciences (5.4\%), physical education $(2.9 \%)$, English $(6.1 \%)$, biology $(1.8 \%)$, religious culture and moral knowledge $(2.9 \%)$, science and technology (4.6), technology design $(2.5 \%)$, chemistry $(1.1 \%)$, counseling $(1.1 \%)$, history $(1.4 \%)$, physics $(0.7 \%)$, philosophy $(0.4 \%)$, visual arts $(0.7 \%)$, music $(0.4 \%)$ and home economics and nutrition $(0.4 \%)$. 


\section{Data Collection and Analysis}

In the present study, the "Technological Pedagogical Content Knowledge Scale" which was developed by Schmidt et al. (2009) and adapted to Turkish by Öztürk and Horzum (2011) was used to collect the data. The required permission was obtained for the use of the scale. This scale is composed of 47 items and 7 factors and is of the five point Likert type. The KMO co-efficient of the study was found to be 0.92 and the Bartlett Test calculated as 15045.20and the result of the Bartlett Test was found to be significant at the level of $0.05(\mathrm{p}=0.000)$. The Cronbach alpha internal consistency co-efficient was found to be 0.96 for the whole scale. These factors were found to be $34.50 \%, 11.96 \%, 9.38 \%, 6.35 \%$, $5.56 \%, 4.28 \%$ and $4.09 \%$, respectively. The total amount of variance which these factors expressed was $76.12 \%$. The first factor in the scale is technological knowledge $(\alpha=0.95)$, the second one is content knowledge $(\alpha=0.95)$, the third is pedagogical knowledge $(\alpha=0.97)$, the fourth is pedagogical content knowledge $(\alpha=0.97)$, the fifth is technological content knowledge $(\alpha=0.93)$, the sixth is technological pedagogical knowledge $(\alpha=0.89)$ and the seventh is technological pedagogical content knowledge $(\alpha=0.94)$. All the values of reliability were at a high level and the researchers stated that the reliability of the scale was high. Content validity and reliability were tested previously by the researchers, so there was no need to test it again.

The scale was distributed to the teachers and the required data was collected and then the data was analyzed via a statistical package. Arithmetic average, percentage, frequency, independent group t-test, one-way variance analysis and LSD were carried out. In the conditions when the distribution was not normal, Mann Whitney U Test was used instead of t-test. The significance level was taken as 0.05 in the study. The levels that are used to comment on arithmetic averages are as follows: "completely disagree" for the average values between the ranges of "1.00-1.80"; "disagree" for the average values between the ranges of "1.81-2.60"; "neutral" for the average values between the ranges of "2.613.40 "; "agree" for the average values between the ranges of "3.41-4.20" and "completely agree" for the values between the ranges of " $4.21-5.00$ ".

\section{Findings and Results}

\subsection{Findings on the Teachers' TPACK Self-Efficacies}

The arithmetic averages and standard deviations related to the teachers' TPACK self-efficacies are given in Table 2 (Appendix A).

When the TK self-efficacies in Table 2 (Appendix A) are examined, it was concluded that teachers who suggested they "agreed" have this self-efficacy. In addition, teachers also stated that they can easily learn technology in an adequate level, they know how to solve the problems, they can adapt to new technologies, they are frequently interested in technology, they have the ability to use it in line with requirements, they have knowledge on various technologies and they also stated that they are unsure about the issue that they have enough time to study with these technologies. Accordingly, we can conclude that teachers see themselves as highly sufficient for TK; however, they do have not enough opportunities to use TK. This situation can be regarded as the result of the fact that teachers need to have sufficient knowledge of their own branches and also on technology, because technology is present at every stage in life today, and teachers have been trying to reach a sufficient level in this domain.

It was determined that teachers' CK self-efficacy levels were at the level of "agree". Teachers gave their views on their knowledge of mathematics, social sciences and physical sciences at the level of agree, while they gave their views on their knowledge on literacy at the level of "completely agree". In addition, teachers also gave their views on their thinking mathematically, historically, scientifically and literarily and about having enough knowledge on different strategies for and ways to develop understanding of mathematics, social sciences, physical sciences and literacy at the level of "agree". It can be concluded from these opinions that the teachers' CK self-efficacy levels on mathematics, social sciences, physical sciences and literacy were at an adequate level. It was also concluded from this study that teachers had a command of the lesson content and their self-efficacies were at high levels.

It was observed that teachers gave their view as "completely agree" for the self-efficacy levels of PK and they possessed this self-efficacy at a high level. It was also concluded that teachers see themselves as adequate and their self-efficacy levels were at a high level for the sub-dimensions of PK in regard to knowing how to assess student performance in the classroom, changing teaching activities according to what students understand or do not understand in the current situation, changing teaching styles according to the students having different learning styles, assessing student learning in many ways, using many different teaching approaches in the classroom environment (cooperative learning, direct learning, questioning learning, problem/project-based learning etc.), being familiar with common student learning misunderstandings and misconceptions and knowing how to organize and maintain classroom management. According to these findings, it can be concluded that teachers have sufficient self-efficacies on the PK dimension which includes classroom management, learning and teaching methods, learning and teaching processes and practices.

Teachers' PCK self-efficacies were found to be at the level of "agree" and it can be stated that teachers have self-efficacy on PCK. Teachers gave their view as "agree" for the items about knowing how to choose effective teaching 
approaches to guide and provide students for the learning of mathematics, literacy, physical sciences and social sciences. So, they stated that their self-efficacy on this issue was at an adequate level. It can be concluded from these results that teachers can teach field information, and they had high levels of self-efficacy on content knowledge from which they benefit in managing the teaching process.

It was determined that teachers gave their views on their having knowledge on the technologies related to the study and understanding of mathematics as "agree", literacy, physical sciences and social sciences. In addition, the total arithmetic average of teachers' opinions on the sub-dimension of TCK was found to be at the level of "agree". These results indicate that teachers have knowledge of the technology they use to teach a specific content to students and also that their self-efficacy levels are at a high level.

Teachers were "agree" on the item concerning harmonizing different teaching activities with the learned technologies. Teachers' self-efficacy levels on choosing the technologies that will increase the effect of teaching approaches for a lesson and also student learning, causing them to think in detail about how the use of technology affects teaching approaches and to have a critical way of thinking about how to use technology in the classroom were found to be at the level of "agree". In addition, the arithmetic average of teachers' perceptions on self-efficacy of TPK was also found to be at the level of "agree". In line with these findings, it can be said that the teachers' TPK self-efficacies were at an adequate level. It can also be concluded that teachers have self-efficacy at a high level in determining the teaching methods and technologies to use, and also thinking about the consequences.

It was concluded that teachers' self-efficacy perceptions on appropriately harmonizing the technologies related to mathematics, literacy, physical sciences and social sciences with appropriate teaching methods, and choosing the technologies to use in the classroom according to what students will learn, how the subject will be taught, and how to develop the teaching were determined to be at the level of "agree". Similarly, teachers' self-efficacy perceptions on using the technologies which include content, technology and teaching methods together in the classroom, leading to colleagues to helping them to coordinate the use of content, technology and teaching methods at school and choosing the technologies that will enrich the content of the lesson were determined to be at the level of "agree". The total score of teachers' self-efficacy perceptions on TPACK is at the level of "agree". This finding shows that teachers have a high level of self-efficacy on TPACK and also they think they can integrate the technology sufficiently in teaching.

\subsection{Findings on Teachers' TPACK Self-Efficacies According to the Variable of Sex}

The results of t-test that was conducted to determine teachers' TPACK self-efficacies according to the variable of sex are given in Table 3 (Appendix B).

We can conclude from Table 3 (Appendix B) that there is a significant difference between teachers' $\mathrm{PK}\left(\mathrm{t}_{(278)}=3.035\right.$, $\mathrm{p}<0.05)$ and TPK $\left(\mathrm{t}_{(278)}=2.124, \mathrm{p}<0.05\right)$ self-efficacies and the variable of sex. In addition, it is also concluded that this difference is in favor of female teachers. It was determined that female teachers see themselves as more sufficient in this self-efficacy when compared with male teachers. According to this finding, it can be thought that female teachers have high levels of self-efficacy on using both the teaching processes and methods and using technology in these processes and methods.

\subsection{Findings on Teachers' TPACK Self-Efficacies According to the Variable of Age}

The results of variance analysis that was conducted to determine teachers' TPACK self-efficacies according to the variable of age are given in Table 4 (Appendix C).

A significant difference was determined between teachers' opinions on TK $\left(F_{(3-276)}=4.041, p<0.05\right)$ and $P C K$ $\left(F_{(3-276)}=3.732, p<0.05\right)$ self-efficacies according to the variable of age. There was differentiation between the opinions of TK self-efficacy realized between the age ranges of 31-35 years and 36 years and above; there is differentiation between the opinions of PCK self-efficacy realized between the age ranges of 21-25 years and 31-35 years. It can be concluded that when the age range of the teachers increase, their TK self-efficacy levels are lower while their PCK self-efficacy levels are higher. It can be concluded from these findings that when the age ranges of teachers increase, they become more unfamiliar with the uses of technology but they have the sufficiency and knowledge to manage the teaching process with the experience that comes with age.

\subsection{Findings on Teachers' TPACK Self-Efficacies According to the Variable of Period of Service}

The results of variance analysis on teachers' TPACK self-efficacies according to the variable of period of service are given in Table 5 (Appendix D).

A significant difference was determined between teachers' opinions of self-efficacies on TK $\left(\mathrm{F}_{(4-275)}=2.606, \mathrm{p}<0.05\right)$ and PCK $\left(\mathrm{F}_{(4-275)}=2.643, \mathrm{p}<0.05\right)$ as is seen in Table 5 (Appendix D). In order to test the differences among the groups the LSD test was conducted. According to the results of the LSD Test, there was a significant difference between teachers with a 6-10 year period of service and those with 11-15 years, 16-20 years and 21 years and above period of service in the sub-dimension of TK; there was a significant difference between teachers with 16-20 years of service and those who 
have a 6-10 year period of service; and also between teachers who have a 21 years and above period of service and those who have a 1-5 year and 6-10 year period of service. When the period of services of the teachers increase, the TK self-efficacy levels decrease while their PCK self-efficacies increase. A similar result was also obtained in the variable of age in this study. We can conclude that when teachers' periods of service increase, their professional competence also increases, while their interest in technology decreases.

\subsection{Findings on Teachers' TPACK Self-Efficacies According to the Variable of Faculty Graduated From}

The results of variance analysis on teachers' TPACK self-efficacies according to the variable of the faculty graduated from are given in Table 6 (Appendix E).

According to Table 6 (Appendix E), a significant difference is observed between teachers' opinions on their self-efficacies for TK $\left(\mathrm{F}_{(3-276)}=4.721, \mathrm{p}<0.05\right)$ and TPK $\left(\mathrm{F}_{(3-276)}=3.348, \mathrm{p}<0.05\right)$ according to the variable of faculty graduated from. The differentiation related to the self-efficacy of TK occurred between the teachers graduated from a faculty of technical education (FTE) and those who graduated from a faculty of education (FE), a faculty of science and letters (FSE) and from other faculties. The differentiation related to the self-efficacy of TPK occurred between teachers who had graduated from FE and those from FTE and FSE. When we examine the self-efficacy levels of teachers in both of the dimensions, it can be seen that teachers who graduated from FTE are at a higher position when compared with other teachers. It may be thought that these teachers have a higher level of a tendency towards the use of technology in terms of both professional and personal usage compared with other teachers.

\subsection{Findings on Teachers' TPACK Self-Efficacies According to the Variable of Branch}

The results of t-test on teachers' TPACK self-efficacies according to the variable of branch are given in Table 7 (Appendix F).

A significant difference was determined between teachers' opinions of self-efficacies of $\mathrm{CK}\left(\mathrm{t}_{(278)}=6.708, \mathrm{p}<0.05\right)$ and TPACK $\left(\mathrm{t}_{(278)}=6.021, \mathrm{p}<0.05\right)$ according to the variable of branch. Classroom teachers think that they have higher levels of self-efficacies of CK and TPACK compared with the branch teachers.

The results of Mann-Whitney $U$ test which was conducted on the sub-dimensions in which the distribution is not homogenous are given in Table 8 (Appendix G).

It can be concluded from Table 8 (Appendix G) that teachers' opinions of their self-efficacies of PCK (MWU=4889.500, $\mathrm{p}<0.05)$ and TCK (MWU $=5402.000, \mathrm{p}<0.05$ ) significantly differentiated according to the variable of branch, and this differentiation is in favor of branch teachers. According to this finding, we can say that classroom teachers have higher levels of self-efficacies on the aforementioned dimension when compared with the teachers in different branches.

In a general overview, it can be seen that all the teachers have self-efficacies of TPACK and its sub-dimensions; however, classroom teacher have higher levels of self-efficacies. The reason for this situation is that classroom teachers have knowledge of all the lessons and they are responsible for only one classroom.

\subsection{Findings on Teachers' TPACK Self-Efficacies According to the Variable of Access to Technology}

The results of t-test on teachers' TPACK self-efficacies according to the variable of access to technology are given in Table 9 (Appendix H).

It can be concluded from the findings given in Table 9 (Appendix H) that teachers' opinions on TPACK self-efficacy do not show significant difference according to the variable of access to the internet. It was determined that teaches have high levels of self-efficacies on TPACK and its sub-dimensions. According to this finding, it can be said that teachers can access the required technology in the school and this situation positively affects their self-efficacies on TPACK.

\subsection{Findings on Teachers' TPACK Self-Efficacies According to the Variable of the Use of Technology Level}

The results of t-test on teachers' TPACK self-efficacies according to the variable of use of technology level are given in Table 10 (Appendix I).

According to the use of technology level of the teachers, there was a significant difference between teachers' opinions on self-efficacies on TK $\left(\mathrm{t}_{(278)}=-5.553, \mathrm{p}<0.05\right)$, TCK $\left(\mathrm{t}_{(278)}=-2.005, \mathrm{p}<0.05\right)$, TPK $\left(\mathrm{t}_{(278)}=-2.472, \mathrm{p}<0.05\right)$ and TPACK $\left(\mathrm{t}_{(278)}=-2.609, \mathrm{p}<0.05\right)$. It was stated that this difference is in favor of teachers who have a sufficient use of technology level. It was detected that teachers who think of themselves as having a sufficient use of technology level have more self-efficacy on this issue. So, we can conclude that the use of technology level is directly proportionate to TPACK self-efficacies.

\subsection{Findings on Teachers' TPACK Self-Efficacies According to the Variable of In-Service Training That is Oriented to the Use of Technology}

The results of t-test on teachers' TPACK self-efficacies according to the variable of in-service training that is oriented to the use of technology are given in Table 11 (Appendix J). 
According to the teachers' receiving in-service training which is oriented to the use of technology, a significant difference was determined between teachers' perceptions on the self-efficacies of $\mathrm{CK}\left(\mathrm{t}_{(278)}=2.114, \mathrm{p}<0.05\right)$ and PCK $\left(\mathrm{t}_{(278)}=2.549, \mathrm{p}<0.05\right)$. This significant difference is in favor of teachers who receive in-service training and this finding is also seen in Table 11 (Appendix J). Teachers gave their view on this as "agree" in regard to their self-efficacies. We can conclude from these results that the receiving of in-service training that is oriented to the use of technology increases the level of self-efficacy.

\section{Conclusion and Discussion}

In the present study, teachers' self-efficacies at TPACK and its sub-dimensions as TC, CK, PK, PCK, TCK, and TPK were examined. It was detected that the level of self-efficacy of the teachers was high and also that they see themselves as efficient. We can say that teachers have high levels of content, pedagogical and technological knowledge perceptions and also they have high level of perceptions for that they realize the interaction of these knowledge in the best way. It was also concluded that teachers know what kind of knowledge they should have together with the use of technology in education and they can develop this knowledge. Teachers focus on teaching approaches that have been resulted from the transformation of technology, content or pedagogy instead of using sophisticated instruments (Kereluik et al., 2010: 17). The statement of a significant relationship between the self-efficacies of TPACK and its sub-dimension is also supported by the results of many studies in this field (Chai, Koh \& Tsai, 2010; Chai, Koh, Tsai \& Tan, 2011; Savaş, 2011; Şahin, 2011). Archambault and Crippen (2009) stated that teachers found themselves efficient at TPACK; however, they found themselves more efficient on the sub-dimensions of PK, CK and PCK in their study which was conducted on online teachers. In technologically enhanced classrooms, great importance should be attached to the teachers' TCPK developments within their professional development in a way that they can realize effective teaching and increase student success (Timur \& Taşar, 2011).

It was concluded from the study that teachers' self-efficacy perceptions of TK, CK, PCK, TCK and TPACK did not change according to sex while the self-efficacy perceptions of PK and TPK changed according to sex. It was determined that the female teachers had higher levels of self-efficacy in these dimensions when compared with the male teachers. It can be said that female teachers have more self-efficacy at using teaching processes and methods, and also technology, together with these elements. Savaş (2011) examined the relationship between science pre-service teachers' TPACK and their genders in his study. In that study Savaş (2011) determined a significant relationship between female and male teachers' project-based TK, PK, PCK, TCK and TPACK. Similarly, in the study by Jamieson-Proctor, Finger and Albion (2010), it was stated that female teachers have higher levels of TPACK efficacy compared with those of male teachers. Koh, Chai and Tsai (2010) found a high level of difference between the perceptions of TK, CK, technology and didactics in favor of male pre-service teachers.

According to the present study, TK and PCK self-efficacies changed according to age and period of service; however, no significant difference existed between self-efficacies of CK, PK, TCK, TPK and TPACK. When the ages and periods of service of the teachers increased, their TK self-efficacy perceptions decreased while their PCK self-efficacies increased. This finding can be related to the idea that teachers' interest in technology decreases when their age and period of service increases, and also when their experience in the profession has increased. Koh et al. (2010) stated that there is a poor relationship between teachers' TPACK, TCK and TK depending on age and also that when teachers' teaching experience increase, their TPACK perceptions also increase.

It was determined in this study that there is a significant difference between teachers' views on TK and TPK self-efficacies according to the faculty they graduated from. It was concluded that teachers who graduated from FTE have higher self-efficacy levels of TK and TPK when compared with other teachers. This finding may be related to the fact that teachers who graduated from FTE are more interested in technology both from their individual and professional perspectives.

In the present study, it was determined that classroom teachers have higher self-efficacy levels of CK, TPACK, PCK and TCK when compared with branch teachers. In studies conducted on teachers, pre-service teachers and educators from different branches, the effectuality, effectiveness and utility of the TPACK model were stressed in environmental planning and assessments (Doering, Scharber, Miler \& Veletsianos, 2009; Graham, Cox \& Velasquez, 2009; Niess et al. 2009; Akkoç, 2010; Bauer, 2010; Williams, Foulger \& Wetzel, 2010; Hofer, Grandgenett, Harris \& Swan, 2011; Otrel-Cass, Khoo \& Cowie, 2012). Canbazoğlu Bilici (2012) emphasized that science pre-service teachers' self-efficacy levels of TPACK increased after TPACK application while Timur and Taşar (2011) stated that science teachers' technology TPACK reliance levels oriented to the use of technology were low throughout science teaching, and this can be compensated for with professional development activities oriented to the use of technologically enhanced environments in science teaching. Zelkowski (2011) found that pedagogical views changed through the use of technology in mathematics teaching throughout the development of TPACK. Similarly, Selim, Tatar and Öz (2009) 
determined that mathematics pre-service teachers' mathematics knowledge levels (CK) and their PK levels were in parallel with the changes in the quality of the computer-supported teaching material that they had prepared. In addition, in the study of Agyei and Voogt (2012) conducted on mathematics teachers, positively significant differences were determined between the teachers' views on their previous and posterior self-efficacies of TPACK and its sub-dimensions (TK, TPK, TCK). The biggest change occurred in the TCK, TPACK, TPK and TK, respectively. Wilson and Wright (2010), in their study conducted on of social sciences teachers, state that there are relations between technology, pedagogy and content and they also emphasized the need for the development of TPACK.

In the present study, it was determined that teachers TPACK self-efficacies did not change according to the situation of access to the internet in their schools and their self-efficacies were found to be sufficient. According to this result, it can be thought that teachers in Turkey are generally sufficiently well-grounded in technology both in terms of access and use. The use of technology for educational purposes is effective on self-efficacy and the exhibiting of positive manners and behaviors (Player-Koro, 2012a; Player-Koro, 2012b). With the integration of information and communication technologies in classrooms, important effects on teachers' perceptions of TCPK and its sub-dimensions occurred (Chai et al., 2010; Tee \& Lee, 2011).

Within the scope of the present study, it was determined that teachers who think that their level of usage of the internet is enough, have higher levels of self-efficacies in TK, TCK, TPK and TPACK. So, it can be thought that the increase of the levels of teachers' using the internet positively affects their TPACK self-efficacies. In the study of Kabakçı Yurdakul (2011), it was stated that pre-service teachers have positive opinions on the effective use of technology and the integration of technology in education. However, in the study of Jamieson-Proctor et al. (2010) in which technology knowledge was measured, pre-service teachers' efficacy perceptions on digital technologies were not found to be at a high level.

It was determined in this study that in-service training oriented to the use of the internet which teachers receive has more positive effects on the sub-dimensions of CK and PCK self-efficacies when compared with the self-efficacy of other sub-dimensions. It can be said that with the increase in teachers' knowledge of the uses of technology, their control on the branch and teaching process increases, and their self-efficacy also increases correspondingly. The perception of the requirement for the use of technology in education is progressively increasing, as a result, technological skills should be focused on in-service training for the development of teachers (Chai et al., 2010). Successful experience models in different program fields in in-service training in the direction of the theoretical framework of TPACK should be used in the planning of activities and providing the efficiency of the curriculum (Rocha et al., 2011). In pre-service training, teachers' views on the utilization of technology in accessing to the learning outputs of future students are being shaped, this enables their understanding of how to bring together content, pedagogy and technology to plan for appropriate and effective teaching (Maddin, 2012).

\section{Recommendations}

The increasing incorporation of technology in teaching causes changes in the learning and teaching processes and applications. So, educators and teachers who train teachers should integrate pedagogical approaches and technology which will assist student understanding in programs and educational practices; the processes should be creative and flexible applications and arrangements should be made to integrate information and communication technologies with teacher development and strategies, teacher trainings and training and education programs. In the training process of teachers or pre-service teachers, several applications should exist both in curriculums and in-service training to enable them to be equipped with the knowledge and skills necessary for the integration of technology in education. In-class arrangements, activities, and practices should be provided for the practice of the TPACK model, and teachers' efficacies should be determined. Such requirements should be realized for both teachers and pre-service teachers separately.

In addition, the following suggestions can be made in relation to the research results:

- In-service training of which aim is to enhance teachers' pedagogical and technological competencies must be focused on. No matter what branch and length of service the participation of all teachers should be provided by developing various trainings and practices in this direction.

- During the education of prospective teachers, sub-structures and program content which are the provider of technological capabilities and accordingly, the development of areas for their content and pedagogical competencies should be provided. Especially, except for the faculties in technical field, enhancer applications should be focused on prospective teachers' competencies, too.

- Technological infrastructure in schools should be re-arranged in accordance with the development and changes of information and communication technologies and teachers should be informed about these issues. In addition, they should be integrated with their content and pedagogical competencies. 


\section{References}

Agyei, D. D., \& Voogt, J. (2012). Developing Technological Pedagogical Content Knowledge in Pre-service Mathematics Teachers through Collaborative Design. Australasian Journal of Educational Technology, 28(4), 547-564.

Akkoç, H. (2010). Investigating the Development of Prospective Mathematics Teachers' Technological Pedagogical Content Knowledge with regard to Student Difficulties: The Case of Radian Concept. Informal Proceedings of the British Society for Research into Learning Mathematics (BSRLM) Day Conference, 13 November 2010 (Vol. 30, No.3, pp. 1-6). Newcastle University, England. http://www.bsrlm.org.uk/IPs/ip30-3/BSRLM-IP-30-3-Full.pdf (Retrieved from 09.02.2013)

Angeli, C., \& Valanides, N. (2009). Epistemological and Methodological Issues for the Conceptualization, Development, and Assessment of ICT-TPCK: Advances in Technological Pedagogical Content Knowledge (TPCK). Computers \& Education, 52(1), 154-168.

Archambault, L., \& Crippen, K. (2009). Examining TPACK among K-12 Online Distance Educators in the United States. Contemporary Issues in Technology and Teacher Education, 9(1), 71-88.

Aşkar, P., \& Davenport, D. (2009). An Investigation of Factors Related to Self-efficacy for Java Programming among Engineering Students. The Turkish Online Journal of Educational Technology - TOJET, 8(1), 26-32.

Bauer, W. (2010). Technological Pedagogical and Content Knowledge for Music Teachers. In D. Gibson \& B. Dodge (Eds.). Proceedings of Society for Information Technology \& Teacher Education International Conference 2010 (pp. 3977-3980). Chesapeake, VA: AACE.

Bos, B. (2011). Professional Development for Elementary Teachers Using TPACK. Contemporary Issues in Technology and Teacher Education, 11(2), 167-183.

Canbazoğlu Bilici, S. (2012). Fen Bilgisi Öğretmen Adaylarının Teknolojik Pedagojik Alan Bilgisi ve Özyeterlikleri. Unpublished Doctoral Thesis. Ankara: Gazi University Institute of Educational Sciences.

Chai, C. S., Koh, J. H. L., \& Tsai, C.-C. (2010). Facilitating PreserviceTeachers' Development of Technological, Pedagogical, and Content Knowledge (TPACK). Educational Technology \& Society, 13(4), 63-73.

Chai, C. S., Koh, J. H. L., Tsai, C.-C., \& Tan, L. L. W. (2011). Modeling Primary School Pre-service Teachers' Technological Pedagogical Content Knowledge (TPACK) for Meaningful Learning with Information and Communication Technology (ICT). Computers \& Education, 57(1), 1184-1193.

Doering, A., Scharber, C., Miller, C., \& Veletsianos, G. (2009). GeoThentic: Designing and Assessing with Technology, Pedagogy, and Content Knowledge. Contemporary Issues in Technology and Teacher Education, 9(3), 316-336.

Ekici, E., Ekici, F. T., \& Kara, İ. (2012). Öğretmenlere Yönelik Bilişim Teknolojileri Öz-yeterlik Algısı Ölçeğinin Geçerlik ve Güvenirlik Çalışması. Pamukkale Üniversitesi Eğitim Fakültesi Dergisi, 31(1), 53-65.

Graham, C., Cox, S., \& Velasquez, A. (2009). Teaching and Measuring TPACK Development in Two Preservice Teacher Preparation Programs. In I. Gibson et al. (Eds.), Proceedings of Society for Information Technology \& Teacher Education International Conference 2009 (pp. 4081-4086). Chesapeake, VA: AACE.

Hammond, T. C., \& Manfra, M. M. (2009). Giving, Prompting, Making: Aligning Technology and Pedagogy within TPACK for Social Studies Instruction. Contemporary Issues in Technology and Teacher Education, 9(2), 160-185.

Harris, J., Mishra, P., \& Koehler, M. J. (2009). Teachers' Technological Pedagogical Content Knowledge and Learning Activity Types: Curriculum-based Technology Integration Reframed. Journal of Research on Technology in Education, 41(4), 393-416.

Hofer, M., Grandgenett, N., Harris, J., \& Swan, K. (2011). Testing a TPACK-Based Technology Integration Observation Instrument. In M. Koehler \& P. Mishra (Eds.), Proceedings of Society for Information Technology \& Teacher Education International Conference 2011 (pp. 4352-4359). Chesapeake, VA: AACE.

Jamieson-Proctor, R., Finger, G., \& Albion, P. (2010). Auditing the TPACK Capabilities of Final Year Teacher Education Students: Are They Ready for the 21st Century? In D. Gronn, \& G. Romeo (Eds) ACEC2010: Digital Diversity. Conference Proceedings of the Australian Computers in Education Conference 2010, Melbourne 6-9 April. Carlton, Victoria: Australian Council for Computers in Education (ACEC).

Kabakçı Yurdakul, I. (2011). Öğretmen Adaylarının Teknopedagojik Eğitim Yeterliklerinin Bilgi ve İletişim Teknolojilerini Kullanımları Açısından İncelenmesi. Hacettepe Üniversitesi Eğitim Fakültesi Dergisi, 40(1), 397-408. 
Kereluik, K., Mishra, P., \& Koehler, M. J. (2010). On Learning to Subvert Signs: Literacy, Technology and The TPACK Framework. The California Reader, 44(2), 12-18.

Koehler, M. J., \& Mishra, P. (2005). What Happens When Teachers Design Educational Technology? The Development of Technological Pedagogical Content Knowledge. Journal of Educational Computing Research, 32(2), 131-152.

Koehler, M. J., \& Mishra, P. (2008). Introducing TPCK. In AACTE Committee on Innovation and Technology (Ed.), Handbook of Technological Pedagogical Content Knowledge (TPCK) for Educators (pp. 3-29). Newyork: Routledge.

Koehler, M. J., \& Mishra, P. (2009). What is technological pedagogical content knowledge? Contemporary Issues in Technology and Teacher Education, 9(1), 60-70.

Koehler, M. J., Mishra, P., Bouck, E.C., DeSchryver, M., Kereluik, K., Shin, T.S. et al. (2011). Deep-play: Developing TPACK for 21st Century Teachers. International Journal of Learning Technology, 6(2), 146-163.

Koehler, M. J., Mishra, P., \& Yahya, K. (2007). Tracing the Development of Teacher Knowledge in a Design Seminar: Integrating Content, Pedagogy and Technology. Computers \& Education, 49(3), 740-762.

Koh, J. H. L., Chai, C. S., \& Tsai, C. C. (2010). Examining the Technological Pedagogical Content Knowledge of Singapore Pre-service Teachers with a Large-scale Survey. Journal of Computer Assisted Learning, 26(6), 563573.

Maddin, E. (2012). Introducing TPCK to Pre-service Teachers through Digital Storytelling. In P. Resta (Ed.), Proceedings of Society for Information Technology \& Teacher Education International Conference 2012 (pp. 1400-1406). Chesapeake, VA: AACE.

MEB-Öğretmen Yetiştirme ve Geliştirme Genel Müdürlüğü. (2012). Talim Terbiye Kurulu 80 Nolu Kararı, Millî Eğitim Bakanlı̆̆ına Bağlı Eğitim Kurumlarına Öğretmen Olarak Atanacakların Atamalarına Esas Olan Alanlar İle Mezun Oldukları Yükseköğretim Programları Ve Aylı Karşıllı̆ı Okutacakları Derslere İlişkin Esaslar. http://oyegm.meb.gov.tr/www/talim-terbiye-kurulu-80-nolu-karari/icerik/35 (Retrieved from 09.02.2013)

Mishra, P., \& Koehler, M. J. (2006). Technological Pedagogical Content Knowledge: A Framework for Integrating Technology in Teacher Knowledge. Teachers College Record, 108(6), 1017-1054.

Mishra, P., \& Koehler, M. J. (2008). Introducing Technological Pedagogical Content Knowledge. Annual Meeting of the American Educational Research Association,March 24-28 2008, (pp. 1-16). New York.

Mishra, P., Koehler, M. J., Zellner, A., \& Kereluik, K. (2012). Thematic Considerations in Integrating TPACK in a Graduate Program. In D. Polly, C. Mims \& K. A. Persichitte (Eds.). Developing Technology-Rich Teacher Education Programs: Key Issues (pp. 1-12). Hershey, PA: IGI Global.

Niess, M. L., Ronau, R. N., Shafer, K.G., Driskell, S.O., Harper, S. R., Johnston, C. et al. (2009). Mathematics Teacher TPACK Standards and Development Model. Contemporary Issues in Technology and Teacher Education, 9(1), 4-24.

Otrel-Cass, K., Khoo, E., \& Cowie, B. (2012). Scaffolding with and through Videos: An Example of ICT-TPACK. Contemporary Issues in Technology and Teacher Education, 12(4), 369-390.

Öztürk, E., \& Horzum, M. B. (2011). Teknolojik Pedagojik İçerik Bilgisi Ölçeği’nin Türkçeye Uyarlanması. Ahi Evran Üniversitesi Eğitim Fakültesi Dergisi, 12(3), 255-278.

Player-Koro, C. (2012a). Factors Influencing Teachers' use of ICT in Education. Education Inquiry, 3(1), 93-108.

Player-Koro, C. (2012b). Reproducing Traditional Discourses of Teaching and Learning: Studies of Mathematics and ICT in Teaching and Teacher Education. Doctoral Thesis in Applied Information Technology towards Science of Education, at the Department of Applied IT, University of Gothenburg. SE-412 96 Gothenburg, Sweden. ISBN: 978-91-628-8466-6.

Rocha, A., Mota, P., \& Coutinho, C. P. (2011). TPACK: Challenges for Teacher Education in the 21st Century. 15th Biennial of the International Study Association on Teachers and Teaching, 4-5, 37-44. University of Minho, Portugal, Braga. http://repositorium.sdum.uminho.pt/bitstream/1822/14823/1/AuroraPedroCD-ProceedingsISATT2011.pdf (Retrieved from 09.02.2013)

Savaş, M. (2011). Investigating Pre-Service Science Teachers' Perceived Technological Pedagogical Content Knowledge Regarding Genetics. Unpublished Master Thesis, Ankara: The Graduate School of Social Sciences of Middle East Technical University.

Schmidt, D. A., Baran, E., Thompson, A. D., Mishra, P., Koehler, M. J., \& Shin, T. S. (2009). Technological Pedagogical Content Knowledge (TPACK): The Development and Validation of an Assessment Instrument for Preservice 
Teachers. Journal of Research on Technology in Education, 42(2), 123-149.

Senemoğlu, N. (2010). Gelişim Öğrenme ve Öğretim Kuramdan Uygulamaya (16. Baskı). Ankara: Pegem Akademi Yay. Eğt. Dan. Hiz. Tic. Ltd. Şti.

Selim, Y., Tatar, E., \& Öz, R. (2009). Matematik Öğretmen Adaylarının Hazırladıkları Öğretim Materyallerinin TÖMAB Modeli ile İncelenmesi. EÜFBED - Fen Bilimleri Enstitüsü Dergisi, 2(2), $239-251$.

Shin T.S., Koehler, M. J., Mishra, P., Schmidt, D. A., Baran, E., \& Thompson, A. D. (2009). Changing Technological Pedagogical Content Knowledge (TPACK) Through Course Experiences. In I. Gibson et al. (Eds.), Proceedings of Society for Information Technology \& Teacher Education International Conference 2009, (pp. 4152-4159). Chesapeake, VA: AACE.

Shulman, L. S. (1986). Those Who Understand: Knowledge Growth in Teaching. Educational Researcher, 15(2), 4-14.

Shulman, L. S. (1987). Knowledge and Teaching: Foundations of the New Reform. Harvard Educational Review, 57(1), $1-22$.

Şahin, İ. (2011). Development of Survey of Technological Pedagogical Content Knowledge (TPACK). TOJET-The Turkish Online Journal of Educational Technology, 10(1), 97-105.

Tee, M. Y., \& Lee, S. S. (2011). From Socialisation to Internalisation: Cultivating Technological Pedagogical Content Knowledge through Problem-based Learning. Australasian Journal of Educational Technology, 27(1), 89-104.

Timur, B. \& Taşar, M. F. (2011). In-Service Science Teachers' Technological Pedagogical Content Knowledge Confidences and Views about Technology-Rich Environments. Center for Educational Policy Studies (CEPS) Journal, 1(4), 11-25.

TPACK.org. (2013). What is TPACK?. http://www.tpack.org/ (Retrieved from 09.02.2013)

Williams, M. K., Foulger, T., \& Wetzel, K. (2010). Aspiring to reach 21st Century Ideals: Teacher Educators' Experiences in Developing their TPACK. In D. Gibson \& B. Dodge (Eds.), Proceedings of Society for Information Technology Teacher Education International Conference 2010 (Vol. 13, pp. 3960-3967). AACE.

Wilson, E., \& Wright, V. (2010). Images over time: The Intersection of Social Studies through Technology, Content, and Pedagogy. Contemporary Issues in Technology and Teacher Education, 10(2), 220-233.

Zelkowski, J. (2011). Developing Secondary Mathematics Preservice Teachers'Technological Pedagogical and Content Knowledge: Influencing Positive Growth. In M. Koehler \& P. Mishra (Eds.), Proceedings of Society for Information Technology \& Teacher Education International Conference 2011 (pp. 4443-4450). Chesapeake, VA: AACE.

\section{Appendix A}

Table 2. Arithmetic averages and standard deviations of teachers' opinions on TPACK self-efficacy

\begin{tabular}{lcc}
\hline Items & X & ss \\
\hline I know how to solve my problems with technology. & 3.94 & 1.05 \\
I can easily learn technology. & 4.24 & 0.91 \\
I can adapt to important new technologies. & 4.16 & 0.91 \\
I am frequently interested in technology. & 3.74 & 1.14 \\
I have knowledge of many and various technologies. & 3.50 & 1.09 \\
I have an ability to use the technology I need. & 3.97 & 0.99 \\
I have had enough opportunity to study different technologies & 3.37 & 1.13 \\
\hline Total & $\mathbf{3 . 8 5}$ & $\mathbf{0 . 8 4}$ \\
\hline I have enough knowledge on mathematics. & 3.76 & 1.20 \\
I can think mathematically. & 3.81 & 1.12 \\
I have various strategies and ways to develop my understanding of math. & 3.61 & 1.13 \\
I have enough knowledge of social sciences. & 3.96 & 1.03 \\
I can think historically. & 3.98 & 0.99 \\
I have various strategies and ways to develop my understanding of social sciences & 3.87 & 1.06 \\
I have enough knowledge of physical sciences. & 3.58 & 1.18 \\
I can think scientifically. & 3.89 & 1.05 \\
I have various strategies and ways to develop my understanding of physical science. & 3.57 & 1.11 \\
I have enough knowledge on literacy. & 4.43 & 0.91
\end{tabular}


I can think literarily.

$4.11 \quad 0.94$

I have various strategies and ways to develop my understanding of literacy.

$4.19 \quad 0.99$

Total

3.90 $\mathbf{0 . 7 6}$

I know how to assess student performances in the classroom.

$4.35 \quad 0.81$

I can change teaching activities according to what the students understand or do not understand in the current situation.

$4.29 \quad 0.86$

I can appropriately change my teaching style according to students with different learning styles.

$4.24 \quad 0.89$

I can assess students learning in many different ways.

$4.29 \quad 0.84$

I can use many different teaching approaches in the classroom environment (cooperative learning, direct learning, questioning learning, problem/project-based learning etc.).

$4.25 \quad 0.83$

I am familiar with common student learning misunderstanding and misconceptions.

$4.18 \quad 0.91$

I know how to organize and maintain classroom management.

$4.31 \quad 0.87$

Total

$4.27 \quad 0.75$

I know how to choose effective teaching approaches to guide student learning in mathematics and to enable them to think mathematically.

I know how to choose effective teaching approaches to guide student learning literacy and to enable them to think appropriately

I know how to choose effective teaching approaches to guide students in physical sciences and enable them to think scientifically.

I know how to choose effective teaching approaches to guide students in social sciences and enable them to think appropriately.

\begin{tabular}{|c|c|c|c|}
\hline & Total & 3.85 & 0.96 \\
\hline \multirow{5}{*}{ 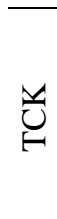 } & I have knowledge of which technology to use to study and understand mathematics. & 3.65 & 1.17 \\
\hline & I have knowledge of which technology to use to study and understand literacy. & 4.05 & 0.97 \\
\hline & I have knowledge of which technology to use to study and understand physical sciences. & 3.63 & 1.15 \\
\hline & I have knowledge of which technology to use to study and understand social sciences. & 3.89 & 1.05 \\
\hline & Total & 3.81 & 0.90 \\
\hline \multirow{6}{*}{$\stackrel{v}{a}$} & $\begin{array}{l}\text { I can choose the technologies that will increase the effect of teaching approaches for a } \\
\text { lesson. }\end{array}$ & 4.12 & 0.81 \\
\hline & I can choose the technologies that will increase student learning from a lesson. & 4.18 & 0.83 \\
\hline & $\begin{array}{l}\text { The teacher training I received enabled me to think in detail about how the use of } \\
\text { technology affects teaching approaches. }\end{array}$ & 3.79 & 1.02 \\
\hline & I have a critical way of thinking about how to use technology in my classroom. & 4.00 & 0.92 \\
\hline & I can customize different teaching activities and the use of technologies that I am learning. & 3.99 & 0.90 \\
\hline & Total & 4.02 & $\mathbf{0 . 7 5}$ \\
\hline \multirow{9}{*}{ 记 } & $\begin{array}{l}\text { I can appropriately harmonize the technologies and teaching approaches for mathematics } \\
\text { and teach mathematics in this way. }\end{array}$ & 3.66 & 1.17 \\
\hline & $\begin{array}{l}\text { I can appropriately harmonize the technologies and teaching approaches for literacy and } \\
\text { teach literacy in this way. }\end{array}$ & 4.03 & 0.98 \\
\hline & $\begin{array}{l}\text { I can appropriately harmonize the technologies and teaching approaches for physical } \\
\text { sciences and teach physical sciences in this way. }\end{array}$ & 3.63 & 1.17 \\
\hline & $\begin{array}{l}\text { I can appropriately harmonize the technologies and teaching approaches for social } \\
\text { sciences and teach social sciences in this way. }\end{array}$ & 3.93 & 1.04 \\
\hline & $\begin{array}{l}\text { I can choose the technologies which I will use in my classroom according to what students } \\
\text { will be learning, how I will teach, and how I can develop my teaching. }\end{array}$ & 4.18 & 0.89 \\
\hline & $\begin{array}{l}\text { I can use the strategies that I learned through my studies in which content, technology and } \\
\text { teaching approaches are brought together }\end{array}$ & 4.09 & 0.90 \\
\hline & $\begin{array}{l}\text { I can lead my colleagues to help them to coordinate the use of content, technology and } \\
\text { teaching approaches. }\end{array}$ & 3.76 & 1.03 \\
\hline & I can choose the technologies that will enrich the content of a lesson. & 4.11 & 0.95 \\
\hline & Total & 3.92 & $\mathbf{0 . 7 9}$ \\
\hline
\end{tabular}




\section{Appendix B}

Table 3. t-test results of teachers' opinions on TPACK self-efficacy according to the variable of sex

\begin{tabular}{|c|c|c|c|c|c|c|c|c|}
\hline \multirow{2}{*}{ Sub-scale } & \multirow{2}{*}{ Gender } & \multirow{2}{*}{$\mathrm{n}$} & \multirow{2}{*}{$\bar{X}$} & \multirow{2}{*}{ Ss } & \multicolumn{2}{|c|}{ Levene's Test } & \multirow{2}{*}{$\mathrm{t}$} & \multirow{2}{*}{$\mathrm{p}$} \\
\hline & & & & & $\mathrm{F}$ & $\mathrm{p}$ & & \\
\hline \multirow{2}{*}{ TK } & Female & 128 & 3.87 & 0.83 & \multirow{2}{*}{0.302} & \multirow{2}{*}{0.583} & \multirow{2}{*}{0.356} & \multirow{2}{*}{0.722} \\
\hline & Male & 152 & 3.83 & 0.86 & & & & \\
\hline \multirow{2}{*}{$\mathrm{CK}$} & Female & 128 & 3.96 & 0.73 & \multirow{2}{*}{0.374} & \multirow{2}{*}{0.541} & \multirow{2}{*}{1.347} & \multirow{2}{*}{0.179} \\
\hline & Male & 152 & 3.84 & 0.78 & & & & \\
\hline \multirow{2}{*}{ PK } & Female & 128 & 4.42 & 0.65 & \multirow{2}{*}{2.476} & \multirow{2}{*}{0.117} & \multirow{2}{*}{$3.035^{*}$} & \multirow{2}{*}{0.003} \\
\hline & Male & 152 & 4.15 & 0.81 & & & & \\
\hline \multirow{2}{*}{ PCK } & Female & 128 & 3.86 & 0.99 & \multirow{2}{*}{0.722} & \multirow{2}{*}{0.396} & \multirow{2}{*}{0.073} & \multirow{2}{*}{0.942} \\
\hline & Male & 152 & 3.85 & 0.92 & & & & \\
\hline \multirow{2}{*}{ TCK } & Female & 128 & 3.85 & 0.87 & \multirow{2}{*}{0.002} & \multirow{2}{*}{0.968} & \multirow{2}{*}{0.775} & \multirow{2}{*}{0.439} \\
\hline & Male & 152 & 3.77 & 0.92 & & & & \\
\hline \multirow{2}{*}{ TPK } & Female & 128 & 4.12 & 0.71 & \multirow{2}{*}{0.030} & \multirow{2}{*}{0.864} & \multirow{2}{*}{$2.124^{*}$} & 0035 \\
\hline & Male & 152 & 3.93 & 0.78 & & & & 0.055 \\
\hline ТРACK & Female & 128 & 3.98 & 0.75 & 1062 & 0.304 & 1195 & 0233 \\
\hline IFACN & Male & 152 & 3.87 & 0.83 & & & 1.195 & \\
\hline
\end{tabular}

$* \mathrm{p}<0.05$

\section{Appendix C}

Table 4. Variance analysis results of teachers' opinions on TPACK self-efficacy according to the variable of age

\begin{tabular}{|c|c|c|c|c|c|c|c|c|c|c|c|}
\hline $\begin{array}{l}\text { Sub- } \\
\text { scale }\end{array}$ & Age & $\mathrm{n}$ & $\bar{X}$ & sS & $\begin{array}{c}\text { Source of } \\
\text { Variance }\end{array}$ & $\begin{array}{l}\text { Sum of } \\
\text { Squares }\end{array}$ & $\mathrm{sd}$ & $\begin{array}{c}\text { Mean } \\
\text { Square }\end{array}$ & $\mathrm{F}$ & $\mathrm{p}$ & LSD \\
\hline \multirow{5}{*}{ 当 } & $\begin{array}{l}\text { Between the } \\
\text { ages of } 21-25\end{array}$ & 12 & 3.74 & 0.73 & $\begin{array}{l}\text { Between } \\
\text { Groups }\end{array}$ & 8.301 & 3 & 2.767 & \multirow{4}{*}{$4.041 *$} & \multirow{4}{*}{0.008} & \multirow{4}{*}{$3-4$} \\
\hline & $\begin{array}{l}\text { Between the } \\
\text { ages of 26-30 }\end{array}$ & 34 & 3.98 & 0.85 & $\begin{array}{l}\text { Within } \\
\text { Groups }\end{array}$ & 188.986 & 276 & 0.685 & & & \\
\hline & $\begin{array}{l}\text { Between the } \\
\text { ages of } 31-35\end{array}$ & 51 & 4.17 & 0.73 & \multirow{2}{*}{ Total } & \multirow{2}{*}{197.287} & \multirow{2}{*}{279} & & & & \\
\hline & $\begin{array}{l}\text { The ages of } \\
36 \text { and over }\end{array}$ & 183 & 3.74 & 0.85 & & & & & & & \\
\hline & Lev & ene: 0 & 87 & & $\mathrm{p}=$ & 399 & & & & & \\
\hline \multirow{5}{*}{$\underline{U}$} & $\begin{array}{l}\text { Between the } \\
\text { ages of 21-25 }\end{array}$ & 12 & 3.72 & 0.48 & $\begin{array}{l}\text { Between } \\
\text { Groups }\end{array}$ & 1.767 & 3 & 0.589 & \multirow{4}{*}{1.014} & \multirow{4}{*}{0.387} & \\
\hline & $\begin{array}{l}\text { Between the } \\
\text { ages of 26-30 }\end{array}$ & 34 & 3.86 & 0.64 & $\begin{array}{l}\text { Within } \\
\text { Groups }\end{array}$ & 160.302 & 276 & 0.581 & & & \\
\hline & $\begin{array}{l}\text { Between the } \\
\text { ages of } 31-35\end{array}$ & 51 & 3.77 & 0.71 & \multirow{2}{*}{ Total } & \multirow{2}{*}{162.070} & \multirow{2}{*}{279} & & & & \\
\hline & $\begin{array}{l}\text { The ages of } \\
36 \text { and over }\end{array}$ & 183 & 3.95 & 0.81 & & & & & & & \\
\hline & Le & ene: 1 & & & $\mathrm{p}=$ & 241 & & & & & \\
\hline \multirow{5}{*}{$\frac{v}{a}$} & $\begin{array}{l}\text { Between the } \\
\text { ages of 21-25 }\end{array}$ & 12 & 4.26 & 0.44 & $\begin{array}{l}\text { Between } \\
\text { Groups }\end{array}$ & 0.530 & 3 & 0.177 & \multirow{5}{*}{0.309} & \multirow{4}{*}{0.819} & \\
\hline & $\begin{array}{l}\text { Between the } \\
\text { ages of 26-30 }\end{array}$ & 34 & 4.30 & 0.71 & $\begin{array}{l}\text { Within } \\
\text { Groups }\end{array}$ & 157.689 & 276 & 0.571 & & & \\
\hline & $\begin{array}{l}\text { Between the } \\
\text { ages of 31-35 }\end{array}$ & 51 & 4.18 & 0.86 & \multirow{2}{*}{ Total } & \multirow{2}{*}{158.219} & \multirow{3}{*}{279} & & & & \\
\hline & $\begin{array}{l}\text { The ages of } \\
36 \text { and over }\end{array}$ & 183 & 4.29 & 0.75 & & & & & & & \\
\hline & \multicolumn{4}{|c|}{ Levene: 0.706} & $\mathrm{p}=$ & 549 & & & & & \\
\hline
\end{tabular}




\begin{tabular}{|c|c|c|c|c|c|c|c|c|c|c|c|}
\hline \multirow{5}{*}{ 记 } & $\begin{array}{l}\text { Between the } \\
\text { ages of } 21-25\end{array}$ & 12 & 3.23 & 1.13 & $\begin{array}{l}\text { Between } \\
\text { Groups }\end{array}$ & 9.925 & 3 & 3.308 & \multirow{4}{*}{$3.732 *$} & \multirow{4}{*}{0.012} & \multirow{4}{*}{$4-1,3$} \\
\hline & $\begin{array}{l}\text { Between the } \\
\text { ages of 26-30 }\end{array}$ & 34 & 3.73 & 0.81 & $\begin{array}{l}\text { Within } \\
\text { Groups }\end{array}$ & 244.662 & 276 & 0.886 & & & \\
\hline & $\begin{array}{l}\text { Between the } \\
\text { ages of } 31-35\end{array}$ & 51 & 3.65 & 1.04 & \multirow{2}{*}{ Total } & \multirow{2}{*}{254.587} & \multirow{2}{*}{279} & & & & \\
\hline & $\begin{array}{l}\text { The ages of } \\
36 \text { and over }\end{array}$ & 183 & 3.97 & 0.92 & & & & & & & \\
\hline & Lev & ne: 0 & 314 & & $\mathrm{p}=$ & 0.487 & & & & & \\
\hline \multirow{5}{*}{ U્U } & $\begin{array}{l}\text { Between the } \\
\text { ages of } 21-25\end{array}$ & 12 & 3.40 & 1.01 & $\begin{array}{l}\text { Between } \\
\text { Groups }\end{array}$ & 2.279 & 3 & 0.760 & \multirow{4}{*}{0.943} & \multirow{4}{*}{0.420} & \\
\hline & $\begin{array}{l}\text { Between the } \\
\text { ages of 26-30 }\end{array}$ & 34 & 3.79 & 0.68 & $\begin{array}{l}\text { Within } \\
\text { Groups }\end{array}$ & 222.398 & 276 & 0.806 & & & \\
\hline & $\begin{array}{l}\text { Between the } \\
\text { ages of 31-35 }\end{array}$ & 51 & 3.78 & 084 & \multirow{2}{*}{ Total } & \multirow{2}{*}{224.677} & \multirow{2}{*}{279} & & & & \\
\hline & $\begin{array}{l}\text { The ages of } \\
36 \text { and over }\end{array}$ & 183 & 3.84 & 0.94 & & & & & & & \\
\hline & Lev & ne: 0 & & & $\mathrm{p}=$ & 0.484 & & & & & \\
\hline \multirow{5}{*}{ 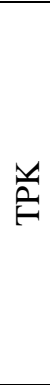 } & $\begin{array}{l}\text { Between the } \\
\text { ages of } 21-25\end{array}$ & 12 & 3.92 & 0.64 & $\begin{array}{l}\text { Between } \\
\text { Groups }\end{array}$ & 1.183 & 3 & 0.394 & \multirow{4}{*}{0.700} & \multirow{4}{*}{0.553} & \\
\hline & $\begin{array}{l}\text { Between the } \\
\text { ages of 26-30 }\end{array}$ & 34 & 3.95 & 0.69 & $\begin{array}{l}\text { Within } \\
\text { Groups }\end{array}$ & 155.547 & 276 & 0.564 & & & \\
\hline & $\begin{array}{l}\text { Between the } \\
\text { ages of 31-35 }\end{array}$ & 51 & 4.15 & 0.71 & \multirow{2}{*}{ Total } & \multirow{2}{*}{156.731} & \multirow{2}{*}{279} & & & & \\
\hline & $\begin{array}{l}\text { The ages of } \\
36 \text { and over }\end{array}$ & 183 & 4.00 & 0.78 & & & & & & & \\
\hline & Lev & ne: 0 & & & $\mathrm{p}=$ & 0.751 & & & & & \\
\hline \multirow{5}{*}{ 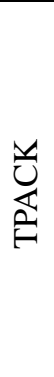 } & $\begin{array}{l}\text { Between the } \\
\text { ages of } 21-25\end{array}$ & 12 & 3.64 & 0.43 & $\begin{array}{l}\text { Between } \\
\text { Groups }\end{array}$ & 1.054 & 3 & 0.351 & \multirow{5}{*}{0.557} & \multirow{4}{*}{0.644} & \\
\hline & $\begin{array}{l}\text { Between the } \\
\text { ages of 26-30 }\end{array}$ & 34 & 3.93 & 0.72 & $\begin{array}{l}\text { Within } \\
\text { Groups }\end{array}$ & 174.010 & 276 & 0.630 & & & \\
\hline & $\begin{array}{l}\text { Between the } \\
\text { ages of 31-35 }\end{array}$ & 51 & 3.92 & 0.70 & \multirow{2}{*}{ Total } & \multirow{2}{*}{175.064} & \multirow{2}{*}{279} & & & & \\
\hline & $\begin{array}{l}\text { The ages of } \\
36 \text { and over }\end{array}$ & 183 & 3.94 & 0.85 & & & & & & & \\
\hline & \multicolumn{4}{|c|}{ Levene:1.646 } & $\mathrm{p}=$ & 0.179 & & & & & \\
\hline
\end{tabular}




\section{Appendix D}

Table 5. The results of variance analysis on teachers' TPACK self-efficacies according to the variable of period of service

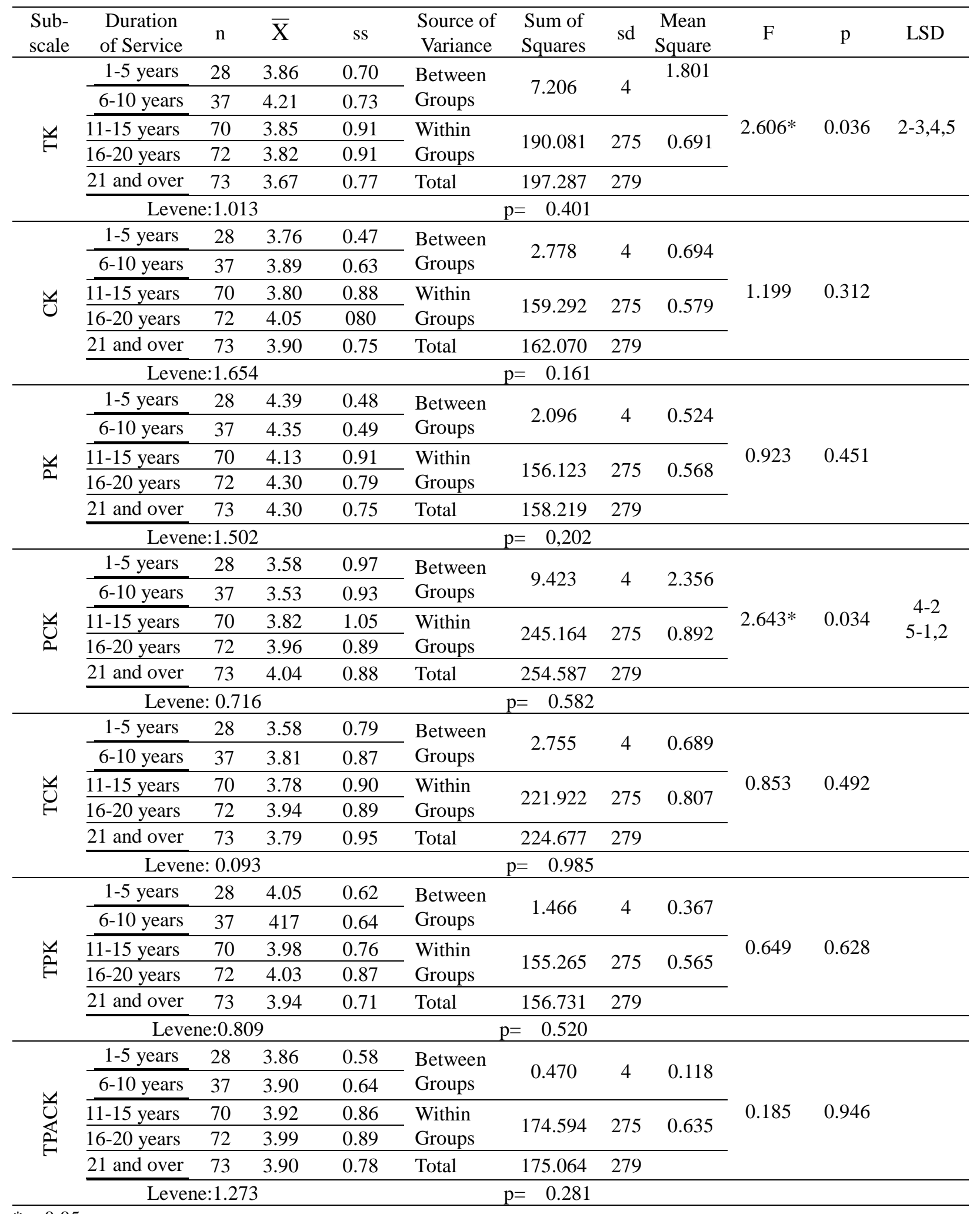

$* \mathrm{p}<0.05$ 


\section{Appendix E}

Table 6. The results of variance analysis on teachers' TPACK self-efficacies according to the variable of faculty graduated from

\begin{tabular}{|c|c|c|c|c|c|c|c|c|c|c|c|}
\hline $\begin{array}{l}\text { Sub- } \\
\text { scale }\end{array}$ & Faculty & $\mathrm{n}$ & $\bar{X}$ & Ss & $\begin{array}{c}\text { Source of } \\
\text { Variance }\end{array}$ & $\begin{array}{c}\text { Sum of } \\
\text { Squares }\end{array}$ & $\mathrm{sd}$ & $\begin{array}{c}\text { Mean } \\
\text { Square }\end{array}$ & $\mathrm{F}$ & $\mathrm{p}$ & LSD \\
\hline \multirow{5}{*}{ 光 } & $\mathrm{FE}$ & 139 & 3.72 & 0.84 & $\begin{array}{l}\text { Between } \\
\text { Groups }\end{array}$ & 9.630 & 3 & 3.210 & \multirow{4}{*}{$4.721 *$} & \multirow{4}{*}{0.003} & \multirow{4}{*}{$2-1,3,4$} \\
\hline & FTE & 13 & 4.56 & 0.62 & $\begin{array}{l}\text { Within } \\
\text { Groups }\end{array}$ & 187.657 & 276 & 0.680 & & & \\
\hline & FSE & 65 & 3.85 & 0.85 & \multirow{2}{*}{ Total } & \multirow{2}{*}{197.287} & \multirow{2}{*}{279} & & & & \\
\hline & Other & 63 & 3.96 & 0.80 & & & & & & & \\
\hline & & Levene & 434 & & $\mathrm{p}=$ & 0.233 & & & & & \\
\hline \multirow{5}{*}{ 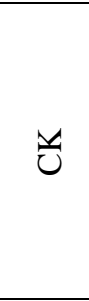 } & $\mathrm{FE}$ & 139 & 3.89 & 0.80 & $\begin{array}{l}\text { Between } \\
\text { Groups }\end{array}$ & 0.254 & 3 & 0.085 & \multirow{4}{*}{0.145} & \multirow{4}{*}{0.933} & \\
\hline & FTE & 13 & 4.02 & 0.42 & $\begin{array}{l}\text { Within } \\
\text { Groups }\end{array}$ & 161.815 & 276 & 0.586 & & & \\
\hline & FSE & 65 & 3.87 & 0.68 & \multirow{2}{*}{ Total } & \multirow{2}{*}{162.070} & \multirow{2}{*}{279} & & & & \\
\hline & Other & 63 & 3.91 & 0.82 & & & & & & & \\
\hline & & Levene & 996 & & $\mathrm{p}=$ & 0.395 & & & & & \\
\hline \multirow{5}{*}{$\frac{v}{a}$} & $\mathrm{FE}$ & 139 & 4.20 & 0.87 & $\begin{array}{l}\text { Between } \\
\text { Groups }\end{array}$ & 2.372 & 3 & 0.791 & \multirow{4}{*}{1.400} & \multirow{4}{*}{0.243} & \\
\hline & FTE & 13 & 4.37 & 0.44 & $\begin{array}{l}\text { Within } \\
\text { Groups }\end{array}$ & 155.847 & 276 & 0.565 & & & \\
\hline & FSE & 65 & 4.42 & 0.54 & \multirow{2}{*}{ Total } & \multirow{2}{*}{158.219} & \multirow{2}{*}{279} & & & & \\
\hline & Other & 63 & 4.27 & 0.70 & & & & & & & \\
\hline & & Levene & 861 & & $\mathrm{p}=$ & 0.136 & & & & & \\
\hline \multirow{5}{*}{$\underset{0}{U}$} & $\mathrm{FE}$ & 139 & 3.88 & 0.96 & $\begin{array}{l}\text { Between } \\
\text { Groups }\end{array}$ & 2.132 & 3 & 0.711 & \multirow{4}{*}{0.777} & \multirow{4}{*}{0.508} & \\
\hline & FTE & 13 & 3.46 & 1.31 & $\begin{array}{l}\text { Within } \\
\text { Groups }\end{array}$ & 252.455 & 276 & 0.915 & & & \\
\hline & FSE & 65 & 3.84 & 0.79 & \multirow{2}{*}{ Total } & \multirow{2}{*}{254.587} & \multirow{2}{*}{279} & & & & \\
\hline & Other & 63 & 3.88 & 1.03 & & & & & & & \\
\hline & & Levene & 106 & & $\mathrm{p}=$ & 0.347 & & & & & \\
\hline & $\mathrm{FE}$ & 139 & 3.79 & 0.91 & $\begin{array}{l}\text { Between } \\
\text { Groups }\end{array}$ & 1.349 & 3 & 0.450 & & & \\
\hline U & FTE & 13 & 4.12 & 0.77 & $\begin{array}{l}\text { Within } \\
\text { Groups }\end{array}$ & 223.328 & 276 & 0.809 & 0.556 & 0.645 & \\
\hline & FSE & 65 & 3.78 & 0.75 & Total & 224677 & 270 & & & & \\
\hline & Other & 63 & 3.81 & 1.03 & & 224.011 & 219 & & & & \\
\hline & & Levene & 994 & & $\mathrm{p}=$ & 0.396 & & & & & \\
\hline & $\mathrm{FE}$ & 139 & 3.89 & 0.83 & $\begin{array}{l}\text { Between } \\
\text { Groups }\end{array}$ & 5.503 & 3 & 1.834 & & & \\
\hline$\frac{1}{2}$ & FTE & 13 & 4.43 & 0.68 & $\begin{array}{l}\text { Within } \\
\text { Groups }\end{array}$ & 151.228 & 276 & 0.548 & $3.348^{*}$ & 0.020 & $\begin{array}{l}2-1 \\
4-1\end{array}$ \\
\hline & FSE & 65 & 4.07 & 0.64 & Total & 156731 & 270 & & & & \\
\hline & Other & 63 & 4.14 & 0.64 & & 150.151 & 219 & & & & \\
\hline & & Levene & 265 & & $\mathrm{p}=$ & 0.287 & & & & & \\
\hline & $\mathrm{FE}$ & 139 & 3.88 & 0.84 & $\begin{array}{l}\text { Between } \\
\text { Groups }\end{array}$ & 1.875 & 3 & 0.625 & & & \\
\hline Uֶ & FTE & 13 & 4.20 & 0.53 & $\begin{array}{l}\text { Within } \\
\text { Groups }\end{array}$ & 173.189 & 276 & 0.627 & 0.996 & 0.395 & \\
\hline F & FSE & 65 & 3.87 & 0.70 & Total & 175064 & 279 & & & & \\
\hline & Other & 63 & 4.01 & 0.81 & lotal & 175.004 & 219 & & & & \\
\hline & & Levene & 296 & & $\mathrm{p}=$ & 0.276 & & & & & \\
\hline
\end{tabular}




\section{Appendix F}

Table 7. The results of t-test on teachers' TPACK self-efficacies according to the variable of branch

\begin{tabular}{|c|c|c|c|c|c|c|c|c|}
\hline \multirow{2}{*}{ Sub-scale } & \multirow{2}{*}{ Branch } & \multirow{2}{*}{$\mathrm{n}$} & \multirow{2}{*}{$\bar{X}$} & \multirow{2}{*}{ ss } & \multicolumn{2}{|c|}{ Levene's Test } & \multirow[b]{2}{*}{$\mathrm{t}$} & \multirow[b]{2}{*}{$\mathrm{p}$} \\
\hline & & & & & $\mathrm{F}$ & $\mathrm{p}$ & & \\
\hline \multirow{2}{*}{ TK } & Classroom T. & 145 & 3.88 & 0.82 & \multirow{2}{*}{0.622} & \multirow{2}{*}{0.431} & \multirow{2}{*}{0.688} & \multirow{2}{*}{0.492} \\
\hline & Branch T. & 135 & 3.81 & 0.87 & & & & \\
\hline \multirow{2}{*}{ CK } & Classroom $\mathrm{T}$. & 145 & 4.17 & 0.64 & \multirow{2}{*}{3.758} & \multirow{2}{*}{0.054} & \multirow{2}{*}{$6.708 *$} & \multirow{2}{*}{0.000} \\
\hline & Branch T. & 135 & 3.60 & 0.78 & & & & \\
\hline \multirow{2}{*}{ PK } & Classroom T. & 145 & 4.34 & 0.72 & \multirow{2}{*}{0.414} & \multirow{2}{*}{0.520} & \multirow{2}{*}{1.568} & \multirow{2}{*}{0.118} \\
\hline & Branch T. & 135 & 4.20 & 0.79 & & & & \\
\hline \multirow{2}{*}{ TPK } & Classroom $\mathrm{T}$. & 145 & 4.08 & 0.70 & \multirow{2}{*}{2.203} & \multirow{2}{*}{0.139} & \multirow{2}{*}{1.426} & \multirow{2}{*}{0.155} \\
\hline & Branch T. & 135 & 3.95 & 0.80 & & & & \\
\hline \multirow{2}{*}{ TPACK } & Classroom $\mathrm{T}$. & 145 & 4.18 & 0.69 & \multirow{2}{*}{2.357} & \multirow{2}{*}{0.126} & \multirow{2}{*}{$6.021 *$} & \multirow{2}{*}{0.000} \\
\hline & Branch T. & 135 & 3.64 & 0.80 & & & & \\
\hline
\end{tabular}

$* \mathrm{p}<0.05$

\section{Appendix G}

Table 8. The results of the Mann-Whitney U test on teachers' TPACK self-efficacies according to the variable of branch

\begin{tabular}{|c|c|c|c|c|c|}
\hline Sub-scale & Branch & $\begin{array}{c}\text { Average of } \\
\text { Rank }\end{array}$ & Sum of Rank & $\mathrm{U}$ & $\mathrm{p}$ \\
\hline \multirow{2}{*}{ PCK } & Classroom T. & 174.28 & 25270.50 & \multirow{2}{*}{$4889.500^{*}$} & \multirow{2}{*}{0.000} \\
\hline & Branch T. & 104.22 & 14069.50 & & \\
\hline & Levene: 6.143 & $\mathrm{p}=0.01$ & & & \\
\hline \multirow{2}{*}{ TCK } & Classroom T. & 170.74 & 24758.00 & \multirow{2}{*}{$5402.000 *$} & \multirow{2}{*}{0.000} \\
\hline & Branch T. & 108.01 & 14582.00 & & \\
\hline & Levene: 9.070 & $\mathrm{p}=0.00$ & & & \\
\hline
\end{tabular}

\section{Appendix $\mathbf{H}$}

Table 9. The results of t-test on teachers' TPACK self-efficacies according to the variable of access to technology

\begin{tabular}{|c|c|c|c|c|c|c|c|c|}
\hline \multirow{2}{*}{ Sub-scale } & \multirow{2}{*}{$\begin{array}{l}\text { Access to } \\
\text { Technology }\end{array}$} & \multirow{2}{*}{$\mathrm{n}$} & \multirow{2}{*}{$\bar{X}$} & \multirow[b]{2}{*}{ ss } & \multicolumn{2}{|c|}{ Levene's Test } & \multirow{2}{*}{$\mathrm{t}$} & \multirow{2}{*}{$\mathrm{p}$} \\
\hline & & & & & $\mathrm{F}$ & $\mathrm{p}$ & & \\
\hline \multirow{2}{*}{ TK } & Yes & 203 & 3.86 & 0.87 & \multirow{2}{*}{0.467} & \multirow{2}{*}{0.495} & \multirow{2}{*}{0.447} & \multirow{2}{*}{0.655} \\
\hline & No & 77 & 3.81 & 0.78 & & & & \\
\hline \multirow{2}{*}{ CK } & Yes & 203 & 3.87 & 0.80 & \multirow{2}{*}{2.212} & \multirow{2}{*}{0.138} & \multirow{2}{*}{-1.053} & \multirow{2}{*}{0.293} \\
\hline & No & 77 & 3.97 & 0.67 & & & & \\
\hline \multirow{2}{*}{ PK } & Yes & 203 & 4.30 & 0.76 & \multirow{2}{*}{0.109} & \multirow{2}{*}{0.742} & \multirow{2}{*}{1.070} & \multirow{2}{*}{0.286} \\
\hline & No & 77 & 4.20 & 0.74 & & & & \\
\hline \multirow{2}{*}{ PCK } & Yes & 203 & 3.84 & 0.98 & \multirow{2}{*}{1.647} & \multirow{2}{*}{0.200} & \multirow{2}{*}{-0.347} & \multirow{2}{*}{0.729} \\
\hline & No & 77 & 3.88 & 0.89 & & & & \\
\hline \multirow{2}{*}{ TCK } & Yes & 203 & 3.82 & 0.93 & \multirow{2}{*}{2.115} & \multirow{2}{*}{0.147} & \multirow{2}{*}{0.422} & \multirow{2}{*}{0.674} \\
\hline & No & 77 & 3.77 & 0.80 & & & & \\
\hline \multirow{2}{*}{ TPK } & Yes & 203 & 4.02 & 0.75 & \multirow{2}{*}{0.190} & \multirow{2}{*}{0.663} & \multirow{2}{*}{0.002} & 0900 \\
\hline & No & 77 & 4.02 & 0.76 & & & & 0.999 \\
\hline ТРACK & Yes & 203 & 3.91 & 0.82 & 0353 & 0553 & -0413 & 0680 \\
\hline IFACN & No & 77 & 3.96 & 0.72 & & 0.553 & -0.415 & 0.000 \\
\hline
\end{tabular}




\section{Appendix I}

Table 10. The results of t-test on teachers' TPACK self-efficacies according to the variable of the use of technology level

\begin{tabular}{|c|c|c|c|c|c|c|c|c|}
\hline \multirow{2}{*}{ Sub-scale } & \multirow{2}{*}{$\begin{array}{c}\text { The Level of } \\
\text { Using Technology }\end{array}$} & \multirow{2}{*}{$\mathrm{n}$} & \multirow{2}{*}{$\overline{\mathrm{X}}$} & \multirow{2}{*}{ SS } & \multicolumn{2}{|c|}{ Levene's Test } & \multirow{2}{*}{$\mathrm{t}$} & \multirow[b]{2}{*}{$\mathrm{p}$} \\
\hline & & & & & $\mathrm{F}$ & $\mathrm{p}$ & & \\
\hline \multirow{2}{*}{ TK } & Insufficient & 53 & 3.30 & 0.75 & \multirow{2}{*}{0.671} & \multirow{2}{*}{0.413} & \multirow{2}{*}{$-5.553 *$} & \multirow{2}{*}{0.000} \\
\hline & Sufficient & 227 & 3.97 & 0.81 & & & & \\
\hline \multirow{2}{*}{ CK } & Insufficient & 53 & 3.78 & 0.80 & \multirow{2}{*}{0.034} & \multirow{2}{*}{0.855} & \multirow{2}{*}{-1.285} & \multirow{2}{*}{0.200} \\
\hline & Sufficient & 227 & 3.92 & 0.75 & & & & \\
\hline \multirow{2}{*}{ PK } & Insufficient & 53 & 4.15 & 0.65 & \multirow{2}{*}{1.846} & \multirow{2}{*}{0.175} & \multirow{2}{*}{-1.312} & \multirow{2}{*}{0.191} \\
\hline & Sufficient & 227 & 4.30 & 0.77 & & & & \\
\hline \multirow{2}{*}{ PCK } & Insufficient & 53 & 3.75 & 0.95 & \multirow{2}{*}{0.038} & \multirow{2}{*}{0.846} & \multirow{2}{*}{-0.854} & \multirow{2}{*}{0.394} \\
\hline & Sufficient & 227 & 3.87 & 0.96 & & & & \\
\hline \multirow{2}{*}{ TCK } & Insufficient & 53 & 3.59 & 0.94 & \multirow{2}{*}{0.931} & \multirow{2}{*}{0.336} & \multirow{2}{*}{$-2.005 *$} & \multirow{2}{*}{0.046} \\
\hline & Sufficient & 227 & 3.86 & 0.88 & & & & \\
\hline \multirow{2}{*}{ TPK } & Insufficient & 53 & 3.79 & 0.69 & \multirow{2}{*}{0.480} & \multirow{2}{*}{0.489} & \multirow{2}{*}{$-2.472 *$} & \\
\hline & Sufficient & 227 & 4.07 & 0.75 & & & & 0.014 \\
\hline$Y K$ & Insufficient & 53 & 3.67 & 0.81 & $0 \Omega \Delta \Omega$ & 0812 & * & 0010 \\
\hline IFACN & Sufficient & 227 & 3.98 & 0.78 & 0.040 & 0.042 & $-2.009^{\circ}$ & 0.010 \\
\hline
\end{tabular}

$* \mathrm{p}<0.05$

\section{Appendix J}

Table 11. The results of t-test on teachers' TPACK self-efficacies according to the variable of in-service training that is oriented to the use of technology

\begin{tabular}{|c|c|c|c|c|c|c|c|c|}
\hline \multirow{2}{*}{ Sub-scale } & \multirow{2}{*}{$\begin{array}{l}\text { In-service } \\
\text { Training }\end{array}$} & \multirow[b]{2}{*}{$\mathrm{n}$} & \multirow{2}{*}{$\bar{X}$} & \multirow[b]{2}{*}{ SS } & \multicolumn{2}{|c|}{ Levene's Test } & \multirow[b]{2}{*}{$\mathrm{t}$} & \multirow[b]{2}{*}{$\mathrm{p}$} \\
\hline & & & & & $\mathrm{F}$ & $\mathrm{p}$ & & \\
\hline \multirow{2}{*}{ TK } & Received & 176 & 3.91 & 0.86 & \multirow{2}{*}{0.130} & \multirow{2}{*}{0.719} & \multirow{2}{*}{1.590} & \multirow{2}{*}{0.113} \\
\hline & Not received & 104 & 3.74 & 0.80 & & & & \\
\hline \multirow{2}{*}{ CK } & Received & 176 & 3.97 & 0.78 & \multirow{2}{*}{0.269} & \multirow{2}{*}{0.604} & \multirow{2}{*}{$2.114^{*}$} & \multirow{2}{*}{0.035} \\
\hline & Not received & 104 & 3.77 & 0.73 & & & & \\
\hline \multirow{2}{*}{ PK } & Received & 176 & 4.31 & 0.81 & \multirow{2}{*}{0.997} & \multirow{2}{*}{0.319} & \multirow{2}{*}{0.932} & \multirow{2}{*}{0.352} \\
\hline & Not received & 104 & 4.22 & 0.64 & & & & \\
\hline \multirow{2}{*}{ PCK } & Received & 176 & 3.96 & 0.93 & \multirow{2}{*}{1.046} & \multirow{2}{*}{0.307} & \multirow{2}{*}{$2.549 *$} & \multirow{2}{*}{0.011} \\
\hline & Not received & 104 & 3.66 & 0.98 & & & & \\
\hline \multirow{2}{*}{ TCK } & Received & 176 & 3.85 & 0.91 & \multirow{2}{*}{0.015} & \multirow{2}{*}{0.902} & \multirow{2}{*}{1.117} & \multirow{2}{*}{0.265} \\
\hline & Not received & 104 & 3.73 & 0.87 & & & & \\
\hline \multirow{2}{*}{ TPK } & Received & 176 & 4.05 & 0.79 & \multirow{2}{*}{3.123} & \multirow{2}{*}{0.078} & \multirow{2}{*}{0.996} & 0320 \\
\hline & Not received & 104 & 3.96 & 0.67 & & & & $0.3<0$ \\
\hline & Received & 176 & 3.98 & 0.80 & 140 & 0826 & 580 & (1) \\
\hline ТРАСК & Not received & 104 & 3.83 & 0.77 & 0.049 & $0.8 \angle 0$ & 1.580 & 0.115 \\
\hline
\end{tabular}

$* \mathrm{p}<0,05$

\section{(cc) $\mathrm{BY}$}

This work is licensed under a Creative Commons Attribution 3.0 License. 